\begin{tabular}{|c|c|}
\hline & \\
\hline 氏 & 柴 田 \\
\hline 学位 の種 類 & 博士（医学） \\
\hline 学，位記 番 号 & 乙第 211 号 \\
\hline 学位授与年月日 & 平成 17 年 12 月 \\
\hline 学位授与の要件 & 学位規則第 4 条第 2 項該当 \\
\hline 学位論文題目 & 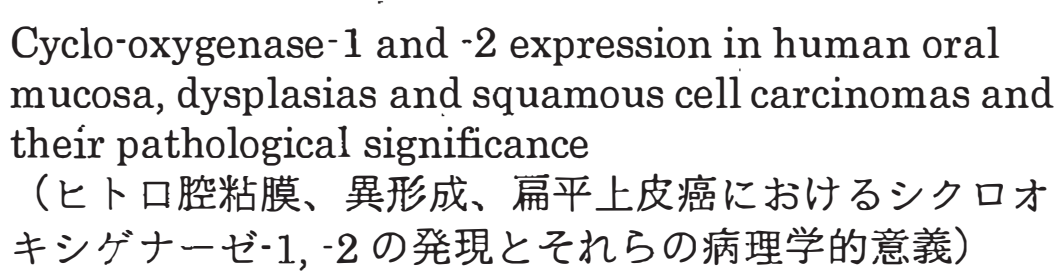 \\
\hline 学位論文審査委員 & （主査） 山 田一夫 \\
\hline & （副査）＼cjkstart井 藤 久 雄＼cjkstart領 家 和男 \\
\hline
\end{tabular}

\title{
学 位論文の内容の要旨
}

シクロオキシゲナーゼ（Cyclo-oxygenase:COX）はアラキドン酸からプロスタグランジンを生 合成する律速醭素の一つであり、COX·1 および COX·2 の 2 種類が同定されている。COX·1 は多 くの組織で桓常的に発現しており、多くの生理機能維持に関与する。一方、COX-2 は炎症などの 刺激により誘導され一過性に発現する。近年、COX·2 の過剩発現が大腸癌、胃癌、肺癌など様々 なヒ卜悪性偱湯において示されている。さらに、COX-2 は血管新生、細胞增殖、アポトーシス阻 害など様々なメカニズムによって癌化に関与していることが報告されている。しかしながら、ロ

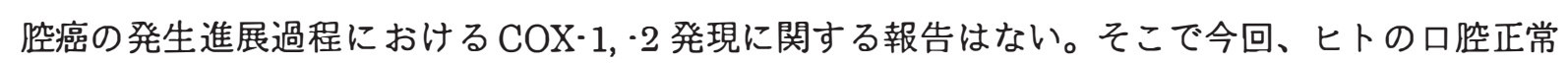
上皮、異形成、扁平上皮癌（Squamous cell carcinoma:SCC）に打る COX-1, - 2 発現について Ki-67, P53,アポトーシス、血管新生とともに病理学的に検討した。

\section{方 法}

4 種類のヒトロ腔 SCC 細胞株（HSC3, HSC4, SCCTF, SCCKN）を培養し、ウェスタンブロ ット法で COX-1,-2 蛋白の発現を調べた。正常口㧚粘膜上皮 9 部位、異形成 65 病变、SCC 50 病変についてホルマリン固定、パラフィン包埋標本を用いて免疫組織化学染色を行った。病理診 断は HE 染色プレパラートを用い、WHO の診断基準によって異形成を㹩度、中等度、高度の 3 種類に、SCC を高分化型、中分化型、低分化型の 3 種類に分類した。免疫組織化学染色はス卜 レプトアビジン・ビオチン・パーオキシダーゼ法にて行い、抗 COX-1 ポリクローナル抗体、抗 COX·2 モノクローナル抗体、抗Ki·67 モノクローナル抗体、抗 P53 モノクローナル抗体、抗 CD34 モノクローナル抗体を用いた。それぞれ 5 ヶ所以上、1000 個の細胞を数え、陽性細胞数をパー 
センテージで表し、ラベリングインデックス（Labelling index:LI）とした。同様に、CD34 陽 性微小血管を数え、微小血管密度（Microve ssel density:MVD）として表した。アポトーシスに ついては TUNEL 法を用い、TUNEL 陽性細胞比率：アポトーシスインデックス (Apoptosis index:AI）として表した。COX-2についてはLI が 20\%未満を低発現、20\%以上を高発現とし、 $\mathrm{COX} \cdot 2$ 発現と他のマーカーとを比較検討した。

\section{結 果}

ウェスタンブロット法で COX-1 蛋白はすべての細胞株で発現がみられた。COX-2 蛋白は 2 細 胞株(SCCTF, SCCKN)で強く発現していた。免疫組織化学染色法では、COX·1の LI は異形成で 最も高く、ついで SCC で高かった。また、SCC の内、低分化型は高分化型（P<0.05）、中分化 型（P<0.05）よりも有意に低かった。COX-2 の LI は正常上皮に比べ異形成（P<0.01）、SCC （P<0.01）で有意に高く、異形成においては異形成の程度が強いほど、SCC においては分化度 が高いほど高值を示した。COX-2 蛋白発現とその他の検討した蛋白発現との相関性は、異形成に おいて COX-1 と COX-2 の発現に正の相関がみられた $(\mathrm{P}<0.05)$ 。しかし、COX·2 の発現と Ki-67, P53, AI, MVD の発現との間には、異形成、SCCいずれも有意な相関はみられなかった。

\section{考 察}

口腔領域の悪性董瘍の中で SCC は最も頻度が高い。また、口哚上皮の異形成は時に SCC へと 発展する前癌病变であり、より高度な異形成ほど SCC に発展しやすい。しかしながら、その癌 化のメカニズムは十分に解明されておらず、口整 SCCにおいて異形成から SCCに発展する病理 生物学的メカニズムを調べることは有用である。今回、免疫組織化学的検索により、COX·1, COX-2 は口腔 SCC 細胞株と同様にヒト口腔粘膜、異形成、SCCにおいて発現がみられ、COX-1, -2 発現は正常組織より異形成、SCC で有意に高いことが明らかになった。

また、COX-2 発現はSCCより異形成で高く、異形成では異形成の程度が強いほど、SCC では 分化度が高いほど有意に高いことが明らかになった。さらに異形成において、COX-1 発現は $\mathrm{COX} \cdot 2$ 発現と正の相関を認めた。大腸、気管支、食道、頭頸部などの器官において癌より前癌病 変において COX-2 発現が高かったとの報告もあるが本研究は口腔粘膜においても COX-1, $\mathrm{COX}-2$ は癌化の初期段階に重要な役割をもつことが示唆された。

異形成、SCC における COX-2 発現と Ki-67, P53, AI, MVD 発現との相関関係については、他 の器官では相関があったとの報告もあるが、今回の研究では有意な相関はみられず、臓器や偅瘍 の特性による違いと思われた。

\section{結 論}

$\mathrm{COX}$-1と COX-2 は口胫癌の異形成を経て癌になる過程において、癌化の初期段階、さらにSCC における細胞分化の程度と密接に関連していると考えられた。 


\section{審 査 結 果 の 要 旨}

本研究はヒト口腔癌の発生進展過程を明らかにすることを目的として、ヒトの口腔正常上皮、 異形成、扁平上皮癌 (SCC) 組織および悪性度の異なる培養 SCC 細胞を用いて、COX-1、COX-2、 Ki-67、P53 の蛋白発現、さらにアポトーシス、血管新生について検討したものである。その結 果、COX·1、COX-2 蛋白の発現は、正常組織より異形成、SCC で有意に高く、また COX-2 の発 現はSCC より異形成で高く、異形成では異形成の程度が強いほど、SCC では分化度が高いほど 有意に高いことより、COX-1 と COX-2 は口腔癌が異形成を経て癌になる初期過程と癌の細胞分 化と関連していることを明らかにした。本論文の内容は、口郢外科学における分子病理学の分野 で明らかに学術の水準を高めたものと認める。 